\title{
Laser Welding of Aluminium Alloys
}

Petra Kvasnová ${ }^{1}$, Daniel Novák ${ }^{1}$, Viktor Novák ${ }^{2}$

${ }^{1}$ Matej Bel University, Faculty of Natural Sciences, Department of Technology, Tajovského 40, 97401 Banská Bystrica, Slovakia.E-mail: petra.kvasnova@umb.sk, daniel.novak@umb.sk

${ }^{2}$ Czech University of Life Sciences Prague, Faculty of Engineering, Department of Electrical Engineering and Automation, Kamýcká 129, 16521 Prague 6, Czech Republic. E-mail: novakviktor@tf.czu.cz

Laser beam welding is an industrial technology that has seen a significant development from the early stages up to the present. Technological process management ensures high product quality as well as enhanced productivity and competitiveness. The aim of the research is to determine the impact of welding parameters by fiber laser beam on the quality of weld joints from aluminium. Basing on the presented quality assessment methods and computer simulation, we evaluate the weld joint samples. Finally, we discuss optimal welding parameters and conditions allowing the production of weld joints of the desired properties.

Keywords: Pure aluminium, Welding, Fiber Laser, Microscopy, Computer simulation

\section{References}

[1] DAVIS, J. R. et al. (1990). Metals Handbook, Properties and Selection, Nonferrous Alloys and Special. In: Purpose Materials, No. 2. ASM International, USA.

[2] BHUSHAN, B., GUPTA, B. K. (1997). Handbook of Tribology, Materials, Coatings and Surface Treatments. Krieger Publishing Company, Florida, USA.

[3] HATCH, J. E. (1984). Aluminum, Properties and Physical Metallurgy. American Society for Metals, Ohio, USA.

[4] MINFORD, J. D. (1993). Handbook of Auminum Bonding. Technology and Data. Marcel Dekker, Inc., USA.

[5] ANDERSON, T. (2004). Aluminum Q \& A. In: Welding Journal, No. 6, pp. 14-19.

[6] TREIBER, H. (1990). Der Laser in der industriellen Fertigungstechnik. Hoppenstedt Technik Tabellen - Darmstadt, Germany.

[7] ARSLAN, S., TURSUN, N., KURTULMUS, F., GÜLEC, D. (2016). Use of thermal images for optimizing burner height, operating pressure, and burner angle of a weed flamer. In: Agronomy Research, Vol. 14, No. 1, pp. 14-24. Estonian University of Life Sciences, Tartu, Estonia.

[8] RADEK, N., MEŠKO, J., ZRAK, A. (2014). Technology of laser forming. In: Manufacturing technology, Vol. 14, No. 3, pp. 428-431. J. E. Purkyně University in Ústí nad Labem, Ústí nad Labem, Czech Republic.

[9] MRAČKOVÁ, E., KRIŠŤÁK, L., KUČERKA, M., GAFF, M., GAJTANSKA, M. (2016). Creation of wood dust during wood processing: Size analysis, dust separation and occupational health. In: Bioresources, Vol. 11, No. 1, pp. 209-222.

[10] SINICINA, N., MARTINOVS, A. (2016). Changes in air ions concentration depending on indoor plants activity. In: Agronomy Research, Vol. 14, No. 1, pp. 236-243. Estonian University of Life Sciences, Tartu, Estonia.

[11] PATEK, M., MIČIAN, M., SLÁDEK, A., KADÁŠ, D. (2016). Numerical Analysis of T-Joint Welding with Different Welding Sequences. In: Manufacturing Technology, Vol. 16, No. 3, pp. 234-238. J. E. Purkyně University in Ústí nad Labem, Ústí nad Labem, Czech Republic.

[12] IGAZ, R., KRIŠTÁK, L., RUŽIAK, I., RÉH, R., DANIHELOVÁ, Z. (2016). Heat transfer during pressing of 3d moulded veneer plywood composite materials. In: Key Engineering Materials, Vol. 68, pp. 131-137.

[13] MAZANCOVÁ, E., RUŽIAK, I., KOŠTIAL, P., GAJTANSKÁ, M., KRIŠŤÁK, L. (2012). The influence of Mn steels ageing on heat transfer phenomena. In: METAL 2012 - Conference Proceedings, 21st International Conference on Metallurgy and Materials, pp. 615-620.

[14] KARDAS, E. (2013). The analysis of quality of ferrous burden materials and its effect on the parameters of blast furnace process. In: Metallurgy, Vol. 52, No. 2, pp. 149-152. 
[15] MEŠKO, J., ZRAK, A., MULCYZK, K., TOFIL, S. (2014). Microstructure analysis of welded joints after laser welding. In: Manufacturing technology, Vol. 14, No. 3, pp. 355-359. J. E. Purkyně University in Ústí nad Labem, Ústí nad Labem, Czech Republic.

[16] TILlOVÁ, E., CHALUPOVÁ, M., HURTALOVÁ, L., ĎURINÍKOVÁ, E. (2011). Quality control of microstructure in recycled Al-Si cast alloys. In: Manufacturing Technology, Vol. 11, pp. 70-76. J. E. Purkyně University in Ústí nad Labem, Ústí nad Labem, Czech Republic.

[17] JONŠTA, P., VLČKOVÁ, I., KRIŠŤÁK, L., ŠPIČKA, I., JONŠTA, Z. (2015). Contribution to the thermal properties of selected steels. In: Metalurgija, Vol. 54, No. 1, Siječanj, pp. 187-190.

[18] DADO, M., SCHWARZ, M., OČKAJOVÁ, A., HNILICA, R., BOROŠOVÁ, D. (2016). Efficiency of local exhaust ventilation system during stainless steel grinding. In: Manufacturing Technology, Vol. 16, No. 1, pp. 49-53. J. E. Purkyně University in Ústí nad Labem, Ústí nad Labem, Czech Republic.

Copyright (C) 2017. Published by Manufacturing Technology. All rights reserved. 